\title{
Stakeholders' participation in hospitals' branding initiatives on social media: a proposal model for building collective brands
}

\section{La participacion de los stakeholders en las iniciativas de branding del hospital en las redes sociales: una propuesta de modelo para construir marcas colectivas}

\author{
Pablo Medina Aguerrebere ${ }^{a}$, Toni González Pacanowski ${ }^{b}$, Eva Medina ${ }^{b}$ \\ a Faculty of Communications, Arts and Sciences, Canadian University Dubai, United Arab Emirates \\ b School of Communication and Psychology, University of Alicante, Spain
}

\begin{abstract}
Introduction: All health organizations face many managerial and economic challenges such as the consolidation of private and international hospitals, the increasingly interest of society for health education issues or the development of telemedicine. In this framework, many organizations prioritize social media as the main corporate communication tool for building a reputed brand in a collective way along with stakeholders. Objectives: This paper aims to identify a communication model allowing hospitals to efficiently apply branding initiatives on social media in order to build a brand in a collective way with stakeholders. Methodology: We carried out a literature review about corporate communication, health communication, branding and social media; and, then, we proposed the PET Model for Branding Hospitals on Social Media. Results and Conclusion: We conclude that hospitals should create a multidisciplinar corporate communication department, implement management initiatives for allowing health professionals have more time for using social media and integrate health education and patient's empowerment in every communication initiative.
\end{abstract}

Keywords: Hospital; Corporate Communication; Brand; Stakeholders; Social Media.

\section{Resumen}

Introducción: Las organizaciones sanitarias hacen frente a muchos desafíos económicos y de gestión, como son la consolidación de los hospitales privados e internacionales, el creciente interés de la gente por la educación sanitaria o el desarrollo de la telemedicina. En este contexto, muchas organizaciones priorizan las redes sociales como principal herramienta de comunicación corporativa para construir una marca reputada de manera colectiva junto con los stakeholders (accionistas). Objetivos: Este artículo tiene como objetivo identificar un modelo de comunicación que permita a los hospitales aplicar de manera eficiente las iniciativas branding (entiquetar) en las redes sociales para construir así una marca colectiva junto con los stakeholders. Metodología: Llevamos a cabo una revisión bibliográfica sobre comunicación corporativa, comunicación de salud, branding y redes sociales; y, posteriormente, proponemos el Modelo PET para la promoción de la marca hospitalaria en redes sociales. Resultados y Conclusión: Los hospitales deben crear un departamento de comunicación corporativa multidisciplinar, implementar iniciativas de gestión para permitir que los profesionales de la salud tengan más tiempo para usar las redes sociales e integrar la educación sanitaria y el empoderamiento del paciente en cada iniciativa de comunicación.

Palabras clave: Hospital; Comunicacion Corporativa; Marca; Stakeholders; Redes Sociales. 


\section{Introduction}

T he development of private and international hospitals, the new interest of people about healthrelated issues and the increasingly economic pressure, force many hospitals to reinvent their corporate communication strategies in order to reinforce their strategic positioning in the health market. Most hospitals prioritize branding initiatives focused on stakeholders' needs and interests rather than journalistic products (corporate magazines, press release, newsletters, etc.). To do that, most of them focus their corporate communication strategies on social media. Even if these platforms constitute a true challenge (confidentiality, patients' rights, scientific dissemination, etc.), many hospitals try to surpass their lack of professional experience in these platforms and use these them so as to create a new corporate communication paradigm focused on the hospital's brand and the satisfaction of all stakeholders' information needs. This paper aims to identify a communication model allowing hospitals to efficiently apply branding initiatives on social media in order to create a collective brand along with stakeholders. To do that, this literature review paper proposes a theoretical analysis about corporate communication, health communication, branding and social media: and, then it explains an online communication model for building collective brands based on an internal functioning structure, ten communication principles, a brand content plan and fifty key performance indicators (PET Model for Online Branding).

\section{Corporate Communication in Hospitals}

Managing efficiently corporate communication has become a strategic priority for most hospitals (Hannawa, García-Jiménez, Candrian, Rossmann, \& Schulz, 2015). This activity determines health professionals' performance, their relationships with patients as well as the hospital internal functioning at a whole (Brent, 2016). Besides, it helps hospitals reinforce their brand positioning, as well as their strategic positioning in the health market (Glover Khalilzadeh, Choy, Prabhakar, Pandharipande, \& Gazelle, 2018). Hospitals manage four main communication activities: interpersonal, internal, external and reputation initiatives (Medina Aguerrebere, 2018).

\section{Interpersonal communication}

Most Schools of Medicine propose in their study plan some courses about language, interpersonal communication and techniques for helping health professionals adapt their speeches to different patients (Hendriks, Van den Putte, De Bruijn, \& Vreese, 2014). Health professionals' skills in interpersonal communication determine patients' engagement with their treatment as well as the doctor and hospital (Mosquera, Melendez, \& Latasa, 2015). These professionals should attend courses for improving their performance when interacting with different patients (illiterate people, children, aggressive patients, etc.) in several situations (bad news, family conflicts, etc.) as a mean to guarantee an efficient interpersonal communication allowing all of them to be aware of their health problems (Archiopoli, Ginossar, Wilcox, Avila, Hillm, \& Oetzel, 2016). Hospitals and Universities work together to constantly update these courses about interpersonal communication for both University's students in Medicine and hospital's doctors (Gilligan et al., 2016).

\section{Internal communication}

In hospitals, most employees have a direct contact with patients and their family, what represents a challenge from a corporate communication point of view (Medina Aguerrebere, 2015). Thanks to internal communication, hospitals can improve their employees' engagement with the organization, their sense of belonging as well as their understanding about the global goals pursued by the hospital (Chan, Yu-Ling, Huxley, \& Evans, 2016). Internal communication aims to create a positive climate allowing employees'hospital to work together in an efficient way and focus mainly its interests on patients' needs and expectations (Blackston \& Pressman, 2016). To do that, experts in internal communication focus their efforts on reinforcing the internal culture among employees (identity, values, mission, vision, culture.) rather than designing journalistc products such as newsletters or magazines (Heide \& Simonsson, 2014).

\section{External communication}

Hospitals interact with many external stakeholders as for instance media companies, public authorities, clients and suppliers (Mira, Lorenzo, \& Navarro, 2014). For this reason, they need to implement a professional approach when managing these stakeholders, which involves creating a corporate communication department, recruiting experts in branding and communication, and implementing an annual communication plan (Esposito, 2017). Hospitals constantly analyse all stakeholders' attitudes and behaviours and identify new opportunities for establishing a corporate dialogue with them (Moser \& Greeman, 2014). They also should adopt a pedagogical 
approach based on disseminating public health related contents allowing stakeholders to improve their knowledge and experience in health (Owusu, Osei, \& Abban, 2014).

\section{Reputation initiatives}

The Corporate Communication Director develops a brand capital allowing the hospital to optimize its internal and external functioning as well as improve its public image and relationships with stakeholders (Medina Aguerrebere, 2018). Reputation determines several aspects such as patients' choices, media companies' perceptions about the hospital or employees' attitudes towards the organization (Johnson, 2014). For example, when hospitals have a good reputation, patients tend to think this organization will provide them with a quality and safe medical service (Mira, Lorenzo, \& Navarro, 2014). Reputation enables hospitals to trigger a positive word-of-mouth about the organization, its services and employees (Blomgren, Hedmo, \& Waks, 2016). For this reason, hospitals should recruit experts in health, economics and corporate communication and create a multidisciplinary Corporate Communication Deparment which leads an internal and external change focused on improving stakehodlers' satisfaction with the hospital's brand (Jahromi, Tatabaee, Abdar, \& Rajabi, 2016).

\section{Hospital's Brand}

Hospital's brand is an intangible asset which helps all corporate communication initiatives be coherent in order to efficiently influence stakeholders' perceptions (Medina Aguerrebere, 2015). According to Esposito (2017), brands disseminate tangible and intangible elements leeting the organization to create an added value appreciated by their stakeholders. Hospital's brand refers to names and logos, but also all patients' experiences and expectations about medical services, employes' attitudes, internal functioning, etc. (Kemp, Jilipalli, \& Becerra, 2014). Managing efficiently a brand has become a priority for all organizations because this intangible asset determines the organization's business models and its economic results (He \& Balmer, 2013). Most hospitals evaluate brands from both a qualitative and quantitative point of view in order to improve their strategic positioning in the market and develop their business (Trepanier \& Gooch, 2014).

Before implementing any communication initiative, the Corporate Communication Director design the company's brand architecture: identity, values, mission, vision and culture. Identity is a strategic element which refers to mains reasons why the organization's founders decided to create the company: these reasons determine its internal and external functioning (Maier, 2016). All communication initiatives led by the company should be consistent with its identity and reinforce it in several ways ( $\mathrm{He} \mathrm{\&}$ Balmer, 2013). Values can be defined as tangible ideas directly related to identity which help employees behave in a proper way so that they can efficiently contribute to achieve all organization's goals (Sheehan, Isaac, 2014). Integrating values in all corporate communication initiatives enables organizations to build an emotional relationship with stakeholders (Zerfass \& Viertmann, 2017). Mission refers to organizational goals pursued by the hospital in the mid term -five or ten years- (Medina Aguerrebere, 2015) as well as all practical initiatives led by the organization to implement this abstract concept in the employes' daily life (Naveen, Anil, \& Smruthi, 2014). Vision is an intangible concept used by companies to describe their organizational objectives in the long term, as well as the practical initiatives they will implement to achieve these objectives and reinforce the company's reputation in the market (Singal \& Jain, 2013). Finally, culture can be defined as the one-of-a-kind way in which all hospital's employes behave every day; culture is an internal element letting the company to become incomparable for both internal and external stakeholders (Nelson, Taylor, \& Walsh, 2014).

The Corporate Communication Director align all these elements -identity, values, mission, vision and culture - in order to create a true addee value to all stakeholders and build a reputed brand in a collective way (Pinho, Rodrigues, \& Dibb, 2014). He should also design an annual corporate communication plan which aims to disseminate the company's brand architecture (identity, values, mission, vision and culture) to all internal and external stakeholders (Gonzalez Pacanowski \& Medina Aguerrebere, 2018). Designing the brand architecture and the annual plan before launching any communication campaign (advertising, public relations, marketing, events, etc.) is essential for hospital to become credible and establish true relationships with stakeholders (Trong, 2014).

Building a reputed, credible and innovative brand constitutes a priority for the Corporate Communication Director, but also for all the hospital's stakeholders, who should actively engage with this collective process (Zerfass \& Viertmann, 2017). Hospital's employees must lead a branding revolution allowing the company to improve its reputation and credibility and reinforce its strategic postioning in the market (Esposito, 2017). Building a brand in a collective way constitutes a 
challenge, but also a strategic opportunity to adapt the company to all stakeholders' perceptions, and improve their engagement with the company's global goals (Owusu, Osei, \& Abban, 2014).

\section{The Collective Construction of Hospital Brands Through Social Media}

Managing efficiently social media for improving the hospital's reputation has become a priority for many hospitals (Visser, Bleijenbergh, Benschop, Van Riel, \& Bloem, 2016). These organizations invest human and economic resources for leading market research about competitors, trends in the health market, patients' expecations and behaviours, etc. (Blombren, Hedmo, \& Waks, 2016) allowing them to implement efficient branding strategies and emotional relationship with stakeholders (Trepanier, 2014). Thanks to this emotional link, hospitals create online brand communities based on social media where all stakeholders, especially patients, can intearact with the company and share information and experiences (Huesch, Currid-Halkett, \& Doctor, 2014). The involvement of hospital's health professionals is essential for these communities to become a true source of medical information (Rupert et al., 2014; Liu, Guo, Wu, \& Vogel, 2014). Social media and brand communities have radically changed all hospitals' corporate communication strategies (Boudewyns, Himelboim, \& Hansen, 2015). Thanks to these platforms, hospitals can build an emotional brand in a collective way with stakeholders (Fernández-Luque \& Bau, 2015) and establish a dialogue about patients' expectations and health related content -diseases, treatments, etc.- (Visser et al., 2016).

In order to efficiently integrate social media platforms and brand communities in hospitals' corporate communication strategies, we propose the PET Model for Branding Hospitals on Social Media. This model is based on four main elements: 1) internal functioning model, 2) ten communication principles, 3) brand content plan and 4) fifty key performance indicators.

According to this model, hospitals implement a Corporate Communication Department which reports directly to the hospital's CEO (Chef Executive Officer) and integrates all communication initiatives led by the organization: public relations, advertising, marketing, events and social media. The Corporate Communication Director defines an annual plan for he whole department as well as for each unit (advertising, public relations, etc.). All these plans should be consistent with the hospital's business plan and validated by the hospital's CEO. Besides, the Corporate Communication Director designs and applies internal protocols for main initiatives led by this department, as for example press conferences, cobranding initiatives, social media campaigns, etc. Finally, concerning the social media unit, its director as well as the other employes in this unit apply these plans and protocols and manage a constantly updated database about stakeholders' behaviours on social media.

All employees working in the social media unit respect ten communication principles enabling the hospital to disseminate an unambiguous image and engage all stakehodlers in a collective brand building process (see Table 1. Communication Principles on Social Media).

First, strategic approach. Hospitals recruit experts in corporate communication able to add value to the hospital's brand and improve all stakeholders' engagement in creating content through social media (Ruiz-Granja, 2015). Second, brand positioning. All branding intiatives through social media are consistent with the organization's brand architecture so that they efficiently influence stakeholders' perceptions and reinforce the company's positioning in the market (Brent, 2016). Third, personal branding. All hospital's health professionals should become brands specialized in different fields so that the hospital converts into a credible source of scientific information for all stakeholders (Liu et al., 2014). Fourth, pedagogical approach. All hospital's communication initiatives on social media should help patients master different health related contents (treatments, prevention, etc.), which helps the organization develop its scientific credibility (Grajales, Sheps, Kendall, Novak-Lauscher, \& Eysenbach, 2014). Fifth, trust relationships. Hospital must figure out some problems related to privacity, security and personal data in order to build a true relationship with stakeholders (Househ, Borycki, \& Kushniruk, 2014).

Sixth, engagement. Hospitals should mobilize stakeholders so as to build a collective brand based on the company's interests and stakeholders' needs (Grajales et al., 2014). Seventh, emotional connexion. Hospitals focus their online communication strategies on patients' feelings and perceptions about the company in order to reinforce their emotional engagement with the hospital (Kemp, Jilipalli, \& Becerra, 2014). Eighth, knowledge management. Doctors and PR experts work together to build and update databases about stakeholders'attitudes and expectations in order to improve the hospital's internal functioning as well all stakeholders' satisfaction (Bubien, 2015). Ninenth, content specialized. Hospitals analyze all stakeholders' health information needs and create scientific content adapted to each of them (McCarroll, Armbruster, Chung, Kim, McKenzie, \& Von Gruenigen, 
2014). And tenth, medical service. Health professionals must integrate social media in their daily work for implementing a collective decision-making process with patients and improving in this way all medical services (Lim, 2016) (Table 1).

Once the hospital's Corporate Communication Director has established an internal functioning model and explained to all its employees these ten communication principles, the next step consist of definin a brand content plan. This annual plan aims to disseminate corporate contents directly related to the hospital's brand architecture using five social media platforms (Twitter, Linkedin, Youtube, Facebook and Instagram) and targeting seven stakeholders (patients, employees, scientific community, public authorities, shareholders, media companies, opinion leaders, society and suppliers). Hospitals should integrate the brand architecture and corporate contents in a creative way and share constantly with stakeholders new inputs pushing them to establish a dialogue with the company (see Table 2. Brand, Content and Targets). To do that, they should carry out previously a market analysis about all stakeholders' information needs.

During the whole year, the hospital's Corporate
Communication Director analze many key performance indicators for the purpose of evaluating whether stakeholders engage -or not- with the organization for building a collective brand. For each social media platform, he establishses an official list of key performance indicators to evaluate the true impact of social media in stakeholders's attitudes and behaviours (see Table 3. Key Performance Indicators).

The hospital's Corporate Communication Director establishes different objectives according to all these key performance indicators, as well as the annual corporate communication plan and the social media annual plan. They take into account all these indicators to evaluate constantly the campaign during the whole year in order to adjust it for bein more efficient. Besides, at the end of year, they analyse all data available in the social media unit's database and update the social media annual plan as well as all protocols used for each platform (Twitter, Linkedin, Youtube, Facebook and Instagram) as a mean to optimize the hospital's effort on social media and improve all stakeholders's engagement with the organization. All these modifications should be consistent with the two annual communication plans (corporate and social media).

Table 1. Communication Principles on Social Media

\begin{tabular}{|c|c|c|}
\hline & Communication Principle & References \\
\hline 1 & Strategic approach & Ruiz-Granja, 2015 \\
\hline 2 & Brand positioning & Brent, 2016 \\
\hline 3 & Personal branding & Liu et al., 2014 \\
\hline 4 & Pedagogical approach & Househ, Borycki, Kushniruk, 2014 \\
\hline 5 & Trust relationship & Grajales et al., 2014 \\
\hline 6 & Engagement & Kem, Jilipalli, Becerra, 2014 \\
\hline 7 & Emotional connexion & Bubien, 2015 \\
\hline 8 & Knowledge management & McCarroll, 2014 \\
\hline 9 & Content specialized & Lim, 2016 \\
\hline 10 & Medical service & \\
\hline
\end{tabular}


Table 2. Brand, Content and Targets

\begin{tabular}{|c|c|c|c|c|}
\hline Month & $\begin{array}{c}\text { Brand } \\
\text { Architecture }\end{array}$ & $\begin{array}{c}\text { Corporate } \\
\text { content }\end{array}$ & Main target & Platforms \\
\hline January & Identity & $\begin{array}{c}\text { Medical information } \\
\text { (treatements, } \\
\text { services, etc.) }\end{array}$ & $\begin{array}{l}\text { Patients } \\
\text { Employees }\end{array}$ & $\begin{array}{l}\text { Twitter, } \\
\text { Linkedin }\end{array}$ \\
\hline February & Mission & $\begin{array}{l}\text { Scientific research } \\
\text { led by health } \\
\text { professionals }\end{array}$ & $\begin{array}{c}\text { External scientific } \\
\text { community } \\
\text { Public authorities }\end{array}$ & $\begin{array}{l}\text { Youtube, } \\
\text { Facebook }\end{array}$ \\
\hline March & Vision & $\begin{array}{c}\text { New business } \\
\text { projects (new } \\
\text { departments, joint } \\
\text { ventures, etc.) }\end{array}$ & $\begin{array}{c}\text { Shareholders } \\
\text { Media companies }\end{array}$ & $\begin{array}{l}\text { Facebook } \\
\text { Youtube }\end{array}$ \\
\hline April & Value 1 & Corporate events & $\begin{array}{l}\text { Public authorities } \\
\text { Opinion leaders }\end{array}$ & $\begin{array}{l}\text { Facebook } \\
\text { Twitter }\end{array}$ \\
\hline May & Value 2 & Learning initiatives & $\begin{array}{l}\text { Patients } \\
\text { Society }\end{array}$ & $\begin{array}{c}\text { Twitter, } \\
\text { Instagram }\end{array}$ \\
\hline June & Culture & $\begin{array}{l}\text { Employees' } \\
\text { innnitiatives }\end{array}$ & $\begin{array}{l}\text { Employees } \\
\text { Suppliers }\end{array}$ & $\begin{array}{l}\text { Linkedin } \\
\text { Instagram }\end{array}$ \\
\hline July & Identity & $\begin{array}{c}\text { Medical information } \\
\text { (treatements, } \\
\text { services, etc.) }\end{array}$ & $\begin{array}{c}\text { Patients } \\
\text { Employees }\end{array}$ & $\begin{array}{l}\text { Twitter, } \\
\text { Linkedin }\end{array}$ \\
\hline August & Mission & $\begin{array}{l}\text { Scientific research } \\
\text { led by health } \\
\text { professionals }\end{array}$ & $\begin{array}{c}\text { External scientific } \\
\text { community } \\
\text { Public authorities }\end{array}$ & $\begin{array}{l}\text { Youtube, } \\
\text { Facebook }\end{array}$ \\
\hline September & Vision & $\begin{array}{l}\text { New business } \\
\text { projects } \\
\text { (departments, joint } \\
\text { ventures, etc.) }\end{array}$ & $\begin{array}{c}\text { Shareholders } \\
\text { Media companies }\end{array}$ & $\begin{array}{l}\text { Facebook } \\
\text { Youtube }\end{array}$ \\
\hline October & Value 3 & Corporate events & $\begin{array}{l}\text { Public authorities } \\
\text { Opinion leaders }\end{array}$ & $\begin{array}{l}\text { Facebook } \\
\text { Twitter }\end{array}$ \\
\hline November & Value 4 & Learning initiatives & $\begin{array}{l}\text { Patients } \\
\text { Society }\end{array}$ & $\begin{array}{l}\text { Twitter, } \\
\text { Instagram }\end{array}$ \\
\hline December & Culture & $\begin{array}{l}\text { Employees' } \\
\text { innnitiatives }\end{array}$ & $\begin{array}{l}\text { Employees } \\
\text { Suppliers }\end{array}$ & $\begin{array}{l}\text { Linkedin } \\
\text { Pinterest }\end{array}$ \\
\hline
\end{tabular}


Table 3. Key Performance Indicators

\begin{tabular}{|c|c|c|}
\hline Social media platform & \multicolumn{2}{|c|}{ Key performance indicators } \\
\hline Facebook (Datapine, 2019a) & $\begin{array}{l}\text { 1. Number of fans } \\
\text { 2. Followers demographics } \\
\text { 3. Page views by sources } \\
\text { 4. Actions on page (likes, content } \\
\text { shared, etc.) } \\
\text { 5. Reach by post type }\end{array}$ & $\begin{array}{l}\text { 6. Post engagement rate } \\
\text { 7. Click-through-rate } \\
\text { 8. Impressions } \\
\text { 9. Frequency } \\
\text { 10. Positive or negative feedback }\end{array}$ \\
\hline Twitter (Datapine, 2019b) & $\begin{array}{l}\text { 1. Average amount of link clicks } \\
\text { 2. Average engagement rate } \\
\text { 3. Average amount of impressions } \\
\text { 4. Top } 5 \text { tweets by engagement } \\
\text { 5. Interests of followers }\end{array}$ & $\begin{array}{l}\text { 6. Followers demographics } \\
\text { 7. Number of followers } \\
\text { 8. Frequency } \\
\text { 9. Positive or negative feedback } \\
\text { 10. Hashtag performance }\end{array}$ \\
\hline Youtube (Datapine, 2019c) & $\begin{array}{l}\text { 1. Total watch time } \\
\text { 2. Total amount of video views } \\
\text { 3. Viewer retention } \\
\text { 4. Video engagement } \\
\text { 5. Number of subscribers }\end{array}$ & $\begin{array}{l}\text { 6. Daily active users } \\
\text { 7. Traffic source } \\
\text { 8. Subscribers demographics } \\
\text { 9. Top } 5 \text { videos by views } \\
\text { 10. Positive or negative feedback }\end{array}$ \\
\hline Linkedin (Datapine, 2019d) & $\begin{array}{l}\text { 1. Followers demographics } \\
\text { 2. Number of followers } \\
\text { 3. Impressions } \\
\text { 4. Reach } \\
\text { 5. Engagement rate }\end{array}$ & $\begin{array}{l}\text { 6. Company update statistics } \\
\text { 7. Viewer information } \\
\text { 8. Contact and network growth } \\
\text { 9. Profile views by job title } \\
\text { 10. Post views \& engagements }\end{array}$ \\
\hline Instagram (Agency Analitics, 2019) & $\begin{array}{l}\text { 1. Followers growth rate } \\
\text { 2. Followers eemographics } \\
\text { 3. Engagement per follower } \\
\text { 4. Website traffic } \\
\text { 5. Link clicks }\end{array}$ & $\begin{array}{l}\text { 6. Comment per Post } \\
\text { 7. Instagram Stories Engagement } \\
\text { 8. Reach } \\
\text { 9. Impressions } \\
\text { 10. Positive or negative feedback }\end{array}$ \\
\hline
\end{tabular}




\section{Conclusion}

Building a reputed, credible brand constitutes a challenge as well as a priority for all hospitals interested in reinforcing their strategic positioning in the health market. For doing that, these organizations need to integrate social media in their professional logic and constantly develop a collective process along with stakeholders in order to influence their perceptions about the organization. Applying the PET Model for Branding Hospitals on Social Media help these organizations to implement a new communication paradigm allowing them to create meaninghful brands for all stakeholders. For the purpose of concluding this paper, we propose three last ideas. First, the hospital's Corporate Communicaton Department and the Social Media Unit should be integrated by experts in branding, economics, mathematics, engineering, public health and medicine; this multidisciplinary structure should work internally according to protocols and annual plans previously approvued by the hospital's CEO. Second, building a credible brand involves all hospital's employees, which means that they need time during their workday for attending courses on corporate communication and social media as well as for using these platforms; in other words, hospitals should recruit more employees so that health professionals can efficiently integrate this new responsibility in their daily schedule. And finally, for properly applying the PET Model, hospitals need to integrate health education and patient's empowerment in every communication initiative so that the hospital brand become a credible source of scientific information for all stakeholders.

\section{References}

Agency Analitics (2019). Instagram Metrics you Should Track to Measure Performance. Document retrieved from: https://agencyanalytics.com/blog/ instagram-metrics-to-measure-success

Archiopoli, A., Ginossar, T., Wilcox, B., Avila, M., Hillm, R., \& Oetzel, J. (2016). Factors of interpersonal communication and behavioral health on medication self-efficacy and medication adherence. AIDS Care, 28(12), 1607-1614. Doi: 10.1080/09540121.2016.1192577.

Blackstone, S., \& Pressman, H. (2016). Patient Communication in Health Care Settings: new Opportunities for Augmentative and Alternative Communication. Augmentative and Alternative Communication, 32(1), 69-79. Doi: 10.3109/07434618.2015.1125947.
Blomgren, M., Hedmo, T., \& Waks, C. (2016). Being Special in an Ordinary Way: Swedish Hospitals' Strategic Web Communication. International Journal of Strategic Communication, 10(3), 177194. Doi: 10.1080/1553118X.2016.1176569

Boudewyns, V., Himelboim, I., \& Hansen, D. (2015). Stigma's Effect on Social Interaction and Social Media Activity. Journal of Health Communication, 20(11), 1337-1345. http://dx.doi.org/10.1080/10810 730.2015.1018604

Brent, R. (2016). Communication Theory and Health Communication Practice: The More Things Change, the More They Stay the Same. Health Communication, 31(1), 1-11. DOI: 10.1080/10410236.2014.923086.

Bubien, Y. (2015). Hôpital 2.0: du virtuel au réel. European Psychiatry, 30(8), S74.

Chan, K., Yu-Ling, M., Huxley, P., \& Evans, S. (2016). Interpersonal communication, community participation and social inclusion among mental health services users. International Behavioral Health Conference: BeHealth 2016 - Multiplicity in action for better health, Hong Kong Baptis University, Hong Kong, January 16th-17th, 2016.

Datapine. (2019a). Facebook Key Performance Indicators and Metrics. Document retrieved from: https://www.datapine.com/kpi-examples-andtemplates/facebook

Datapine. (2019b). Twitter Key Performance Indicators and Metrics. Document retrieved from: https://www. datapine.com/kpi-examples-and-templates/twitter

Datapine. (2019c). Youtube Key Performance Indicators and Metrics. Document retrieved from: https://www.datapine.com/kpi-examples-andtemplates/youtube

Datapine. (2019d). Linkedin Key Performance Indicators and Metrics. Document retrieved from: https://www.datapine.com/kpi-examples-andtemplates/linkedin

Esposito, A. (2017). Hospital branding in Italy: A pilot study based on the case method. Health Marketing Quarterly, 34(1), 35-47. Doi: 10.1080/07359683.2016.1275211.

Fernandez-Luque, L., \& Bau, T. (2015). Health and social media: perfect storm of information. Healthcare Informatics Research, 21(2), 67-73. Doi:http:/l dx.doi.org/10.4258/hir.2015.21.2.67. 
Gilligan, C., James, E.L., Snow, P., Outram, S., Ward, B.M., Powell, M., ... Lynagh, M.C. (2016). Interventions for improving medical students' interpersonal communication in medical consultations. Cochrane Database of Systematic Reviews, 11, 1-14. Doi: 10.1002/14651858.CD012418.

Glover, M., Khalilzadeh, O., Choy, G., Prabhakar, A., Pandharipande, P., \& Gazelle, S. (2015). Hospital Evaluations by Social Media: A Comparative Analysis of Facebook Ratings among Performance Outliers. Journal of General Internal Medicine, 30(10), 1440-1446. Doi: 10.1007/s11606-015-3236-3.

Gonzalez Pacanowski, T., \& MedinaAguerrebere, P. (2018). El rol de las redes sociales en la difusión de la identidad corporativa de los hospitales españoles. Revista de la Asociación Española de Investigación de la Comunicación, 5(10), 30-38.

Grajales, F., Sheps, S., Kendall, H., Novak-Lauscher, H., \& Eysenbach, G. (2014). Social Media: A Review and Tutorial of Applications in Medicine and Health Care. Journal of Medical Internet Research, 16(2), e13. Doi: doi:10.2196/jmir.2912.

Hannawa, A., García-Jiménez, L., Candrian, C., Rossmann, C., \& Schulz, P. (2015). Identifying the Field of Health Communication. Journal of Health Communication, 20(5), 521-530. DOI: 10.1080/10810730.2014.999891.

He, H., \& Balmer, J. (2013). A grounded theory of the corporate identity and corporate strategy dynamic. European Journal of Marketing, 47(3-4), 401430. Doi: 10.1108/03090561311297391.

Heide, M., \& Simonsson, C. (2014). Developing internal crisis communication New roles and practices of communication professionals. Corporate Communications: An International Journal, 19(2), 128-146. Doi: http://dx.doi.org/10.1108/CClJ09-2012-0063.

Hendriks, H., Van den Putte, B., De Bruijn, G., \& Vreese, C. (2014). Predicting Health: The Interplay Between Interpersonal Communication and Health Campaigns. Journal of Health Communication, 19, 625-636. Doi: 10.1080/10810730.2013.837552.

Househ,M.,Borycki,E.,\&Kushniruk,A.(2014).Empowering patients through social media: The benefits and challenges. Health Informatics Journal, 20(1), 50-58. Doi: 10.1177/1460458213476969.
Huesch, M., Currid-Halkett, E., \& Doctor, J. (2014). Public hospital quality report awareness: evidence from National and Californian Internet searches and social media mentions, 2012. BMJ Open, 4, e004417. Doi:10.1136/bmjopen-2013-004417.

Jahromi, V., Tatabaee, S., Abdar, Z., \& Rajabi, M. (2016). Active listening: The key of successful communication in hospital managers. Electronic Physician, 8(3), 2123-2128. Doi:http://dx.doi.org/10.19082/2123

Johnson, K. (2014). The Link Between Patient Experience and Hospital Reputation. National Research Corporation, 1-8.

Kemp, E., Jillapalli, R., \& Becerra, E. (2014). Healthcare branding: developing emotionally based consumer brand relationships. Journal of Services Marketing, 28(2), 126-137. Doi: http://dx.doi. org/10.1108/JSM-08-2012-0157.

Lim, W. (2016). Social media in medical and health care: opportunities and challenges. Marketing Intelligence \& Planning, 34(7), 964-976. Doi: http://dx.doi.org/10.1108/MIP-06-2015-0120.

Liu, X., Guo, X., Wu, H., \& Vogel, D. (2014). Doctor's Effort Influence on Online Reputation and Popularity. Smart Health - International Conference, ICSH, Beijing, China, July 10-11, 2014.

Maier, C. (2016). Beyond Branding: Van Riel and Fombrun's Corporate Communication Theory in the Human Services Sector. Qualitative Research Reports in Communication, 17(1), 27-35. Doi: 10.1080/17459435.2015.1088892.

McCarroll, M., Armbruster, S., Chung, J., Kim, J., McKenzie, A., \& Von Gruenigen, V. (2014). Health Care and Social Media Platforms in Hospitals. Health Communication, 29(9), 947-952. Doi: 10.1080/10410236.2013.813831

Medina Aguerrebere, P. (2018). L'impact des réseaux sociaux sur la gestion professionnelle de la communication hospitalière au Royaume-Uni. Observatorio. Obs* Journal, 11(4), 13-25.

Medina Aguerrebere, P. (2015). Management of the internal communication in hospitals: conceptual framework and implementation model. The International Journal of Communication and Health, 5, 53-65.

Mira, J., Lorenzo, S., \& Navarro, I. (2014). Hospital Reputation and Perceptions of Patient Safety. Medical Principles and Practice, 23, 92-94. Doi: 10.1159/000353152. 
Mosquera, M., Melendez, V., \& Latasa, P. (2015). Handling Europe's first Ebola case: internal hospital communication experience. American Journal of Infection Control, 43(4), 386-389. Doi: 10.1016/j. ajic.2015.01.015.

Naveen, K., Anil, J., \& Smruthi, T. (2014). Impact of healthcare marketing and branding on hospital services. International Journal of Research Foundation of Hospital \& Healthcare Administration, 2(1), 19-24. Doi: 10.5005/jpjournals-10035-1010.

Nelson, W., Taylor, E., \& Walsh, T. (2014). Building an Ethical Organizational Culture. The Health Care Manager, 33(2), 158-164. Doi: 10.1097/ HCM.0000000000000008.

Owusu, K., Osei, H., \& Abban, E. (2014). Organizational Communication in Public Health Institutions. International Journal of Business and Management, 9(11), 179-188. Doi: http://dx.doi. org/10.5539/ijbm.v9n11p179.

Pinho, J., Rodrigues, A., \& Dibb, S. (2014). The role of corporate culture, marketorientationand organizational commitment in organizational performance. Journal of Management Development, 33(4), 374-398. Doi: 10.1108/JMD-03-2013-0036.

Ruiz-Granja, M. (2015). Análisis comunicacional de páginas web hospitalarias. El caso de los hospitales sevillanos. Revista Española de Comunicación en Salud, 6(2), 138-56.

Rupert, D., Moultrie, R., Read, J., Amoozegar, J., Bornkessel, A., Donoghue, A., \& Sullivan, H. (2014). Perceived healthcare provider reactions to patientand caregiver use of online health communities. Patient Education and Counseling, 96(3), 320-326. Doi: http://dx.doi.org/10.1016/j.pec.2014.05.015.

Singal, A., \& Jain, A. (2013). An empirical examination of the influence of corporate vision on internationalization. Strategic Change, 22(5-6), 243-257. Doi: 10.1002/jsc.1937.

Trepanier, S., \& Gooch, P. (2014). Personal Branding and Nurse Leader Professional Image. Nurse Leader, 12(3), 51-57. http://dx.doi.org/10.1016/j. mnl.2014.03.005.

Trong, L. (2014). Corporate governance and brand performance. Management Research Review, 37(1), 45-68. Doi: 10.1108/MRR-08-2012-0183.

Visser, L., Bleijenbergh, I., Benschop, Y., Van Riel,
A., \& Bloem, B. (2016). Do online communities change power processes in healthcare? Using case studies to examine the use of online health communities by patients with Parkinson's disease. British Medical Journal, 6, e012110. Doi:10.1136/ bmjopen-2016-012110.

Zerfass, A., \& Viertmann, C. (2017). Creating business value through corporate communication: A theorybased framework and its practical application. Journal of Communication Management, 21(1), 68-81. Doi: https://doi.org/10.1108/JCOM07-2016-0059 